\title{
The relationship between consumer ethnocentrism, cosmopolitanism and product country image among younger generation consumers: The moderating role of country development status
}

\author{
Zhongqi Jin $^{\mathrm{a}, 1, *}$, Richard Lynch ${ }^{\mathrm{a}, 1}$, Samaa Attia ${ }^{\mathrm{b}, 1}$, Bal Chansarkar ${ }^{\mathrm{a}, 1}$, Tanses Gülsoy ${ }^{\mathrm{c}, 1}$, \\ Paul Lapoule $^{\mathrm{d}, 1}$, Xueyuan Liu ${ }^{\mathrm{e}, 1}$, William Newburry ${ }^{\mathrm{f}, 1}$, Mohamad Sheriff Nooraini ${ }_{\mathrm{g}, 1}$, \\ Ronaldo Parente $^{\mathrm{f}, 1}$, Keyoor Purani ${ }^{\mathrm{h}, 1}$, Marius Ungerer $^{\mathrm{i}, 1}$ \\ a Middlesex University Business School, The Burroughs, London NW4 4BT, UK \\ ${ }^{\mathrm{b}}$ Business Administration Department, Faculty of Business Administration, Economics \& Political Science, The British University in Egypt (BUE), Egypt \\ c Beykent University, Istanbul 34396, Turkey \\ ${ }^{\mathrm{d}}$ NOVANCIA Business School, 3 rue Armand Moisant - CS 81560, 75731 Paris Cedex 15, France \\ ${ }^{\mathrm{e}}$ Economics and Management School, Wuhan University, Wuhan 430072, China \\ ${ }^{\mathrm{f}}$ Florida International University, Department of Management $\mathcal{E}$ International Business, RB 341B, USA \\ ${ }^{\mathrm{g}}$ Arshad Ayub Graduate Business School, Universiti Teknologi MARA, Malaysia \\ ${ }^{\mathrm{h}}$ Indian Institute of Management, Kozhikode, IIMK Campus PO, Kozhikode 673570, Kerala, India \\ ${ }^{\mathrm{i}}$ University of Stellenbosch Business School, PO Box 610, Bellville 7535, South Africa
}

\section{A R T I C L E I N F O}

\section{Article history:}

Received 17 December 2013

Received in revised form 15 July 2014

Accepted 20 August 2014

Available online $\mathrm{xxx}$

\section{Keywords:}

Cosmopolitanism

Country development status

Developed countries

Developing countries

Ethnocentrism

Global strategy

Product country image

\begin{abstract}
A B S T R A C T
Although the differences between developed and developing countries have been extensively studied in the context of globalization strategies, few studies have so far been conducted on the relationship between country development status and the possession by countries of a favorable (or unfavorable) product country image ( $\mathrm{PCI}$ ). Moreover, the results of such studies to date have been inconclusive. The purpose of this paper is to investigate the moderating role of country developmental status on PCI coupled with two antecedents of PCI, namely consumer ethnocentrism and cosmopolitanism. The paper also distinguishes between the PCI of the home and foreign country images of respondents. We test a new model that incorporates these constructs with a sample of 2655 younger generation consumers. The results show that country development status moderates some relationships but does not moderate others. These findings have significant implications for international companies from both developed and developing countries when developing global strategy.

( $) 2014$ The Authors. Published by Elsevier Ltd. This is an open access article under the CC BY license
\end{abstract} (http://creativecommons.org/licenses/by/3.0/).

\section{Introduction}

Differences in cultural, political and economic factors (Buckley \& Ghauri, 2004; Ghemawat, 2001; Ghemawat \& Ghadar, 2000) have made it difficult for multi-national enterprises to gain the benefits of a fully integrated global strategy as well as challenging the theories surrounding globalization (Birkinshaw \& Morrison, 1995; Kipnis, Kubacki, Broderick, Siemieniako, \& Pisarenko, 2012;

\footnotetext{
* Corresponding author. Tel.: +44 02084115571; fax: +4402082038728.

E-mail addresses: Z.Jin@mdx.ac.uk (Z. Jin), R.Lynch@mdx.ac.uk (R. Lynch), Samaa.Attia@Bue.edu.eg (S. Attia),bal_chansarkar@yahoo.co.uk (B. Chansarkar), tansesgulsoy@beykent.edu.tr (T. Gülsoy), plapoule@novancia.fr (P. Lapoule), x.liu@whu.edu.cn (X. Liu), newburry@fiu.edu (W. Newburry), nooraini@salam.uitm.edu.my (M.S. Nooraini),rcparent@fiu.edu (R. Parente), kpurani@iimk.ac.in (K. Purani), marius.ungerer@usb.ac.za (M. Ungerer).

${ }^{1}$ Apart from the first and the second authors, the rest of authors are arranged in alphabetical order.
}

Rugman \& Oh, 2008; Rugman \& Verbeke, 2003). However, trends in global branding, global transport, improved international communications, manufacturing outsourcing and low labor-cost manufacturing have all helped to reduce country boundaries, standardize customer tastes and increase cosmopolitan perceptions in many countries (Porter, 1986; Ter Hofstede, Steenkamp, \& Wedel, 1999; Usunier, 2011; Yip, 2000). These changes have applied equally in both developed and developing countries with products, for example, from companies like McDonalds, Apple and Gucci being available worldwide. In spite of this trend toward some degree of convergence, income per head between the richest and poorest country in the world has diverged from 5:1 in the 18th Century to $400: 1$ in the late 20th Century according to one study (Landes, 1998).

More generally, economic differences between developed and developing countries have been extensively studied (see, for 
example, Cantwell, 1989; Fagerburg \& Verspagen, 2002). Typically such studies have included evidence on wealth per head of the population in different countries - see, for example, the World Bank Report 2012 - thus making it an essential measure of country development status. It has been widely accepted for many centuries and is fundamental to the foundations of marketing that consumer wealth is a prime determinant of purchasing behavior. Country development status captures this concept with comparisons typically being made between developed and developing countries.

More recently, it has been established (see, for example, the reviews in Dimitrovic \& Vida, 2010; Kaynak \& Kara, 2002; Papadopoulos \& Heslop, 1993; Roth \& Diamantopoulos, 2009) that Product Country Image (PCI) influences purchasing decisions around the world. This is important for companies from both developed and developing countries because they have the opportunity across such countries to exploit, to hide and to support the $\mathrm{PCI}(\mathrm{s})$ associated with their companies. Such research therefore remains of significant relevance to international business (Chabowski, Samiee, \& Hult, 2013).

PCI matters in purchasing decisions because it reflects the extent to which country preference can over-ride global standardization. However, although there are some studies that have examined the influence of country development status on PCI, they remain few in number and the results to date have been inconclusive. Some papers have shown that consumers perceive products from developing countries to have lower quality than those from developed countries (Özsomer, 2012; Pappu, Quester, \& Cooksey, 2007; Usunier \& Cestre, 2008). Other studies have suggested that the increase in off-shore manufacturing in developing countries may have altered such perceptions (Chao, 1993). Moreover, many studies have been only among developed countries (Dinnie, 2004; Leonidou, Palihawadana, \& Talias, 2007). Very few PCI studies have addressed the broader comparison of developed versus developing countries (Özsomer, 2012; Sharma, 2011). Such evidence is important for managers that are developing global strategies because country economic development may influence PCI and, in turn, the scope and content of global standardization strategies (Hannerz, 1990; Ter Hofstede et al., 1999). Equally, such managers may be attracted by the faster economic growth of some developing countries when seeking new opportunities and wish to consider the PCI implications (Klein, Ettenson, \& Krishnan, 2006).

Importantly for global decision making, it is not enough to know that there are differences in PCI between developed and developing countries. For the evidence to be actionable for managers, the reasons for such differences need to be understood (Dimitrovic \& Vida, 2010). There have been a large number of studies that have investigated various consumer antecedents and their influence on PCI, such as materialism, consumer ethnocentrism, value consciousness, and cosmopolitanism. However, many of the findings of such antecedents focus primarily on developed countries and, moreover, are inconclusive with regard to developing countries (Roth \& Diamantopoulos, 2009; Sharma, 2011). For example, Klein et al. (2006) concluded that consumer ethnocentrism had a negative effect on the evaluation of foreign products, whereas Wang and Chen (2004) noted different effects based on different consumption tendencies. Thus there is a 'major gap' in the literature relating to PCI and its antecedents in the context of increased globalization (Dimitrovic \& Vida, 2010). It is not practical for a single research project to explore all such antecedents (Sharma, 2011). We have selected two that have previously been widely studied, namely Consumer Ethnocentrism (CET) and Cosmopolitanism (COS), and that are relevant to issues in globalization and country development status (Cleveland, Laroche, \& Papadopoulos, 2009).
Given the limited and conflicting empirical evidence in this area, the purpose of this paper is to examine the moderating effect of country economic development status on the relationship between PCI and two of its antecedents, CET and COS. We undertake this task by developing a new embedded model that incorporates five constructs: country development status, PCIs for both home and foreign countries, CET and COS. We then test the model empirically via a sample of younger generation consumers ( $n=2655)$ from three developed and eight developing nations. We contribute to the literature by integrating PCIs with country economic development status in globalization strategy, both of which have relevance to international business.

The paper is organized in five sections. First, we review the literature and develop our proposed research hypotheses and framework. We then outline the research methodology and evidence used in the study to test the hypotheses. Next, the research findings are described and analyzed. The results are then discussed and conclusions drawn. Finally, the paper identifies the managerial implications.

\section{Conceptual framework and hypotheses}

Product Country Image (PCI) and the related concept of Country-of-Origin remain significant areas of research in international business (Chabowski et al., 2013). There are two main streams in the PCI literature, one describing the general image of the country in terms of its economy, politics and technological development (Martin \& Eroglu, 1993; Verlegh \& Steenkamp, 1999) and the other focusing on the attributes of its products (Han \& Terpstra, 1988; Roth \& Romeo, 1992). PCI is multidimensional in its nature, covering products and brands and the many countries that may be involved in their production and marketing (Papadopoulos \& Heslop, 1993; Samiee, 2010). The general conclusion on PCI research is that "although the size of the effect may vary across products, consumers and situations, the impact of PCI is real, pervasive and measurable" (Heslop, Papadopoulos, Dowdles, Wall, \& Compeau, 2004, p. 1178).

Perhaps because of its wide scope, the PCI concept lacks clear definition (Wang et al., 2012). For the purposes of this research, we adopt the following definition of $\mathrm{PCI}$ : the "overall perception consumers form of products from a particular country, based on their prior perceptions of the country's production and marketing strengths and weaknesses" (Roth \& Romeo, 1992, p. 480). We have chosen this definition because it is consistent with the prime purpose of this paper which explores the extent to which PCI moderates globalization strategies, particularly in production and marketing, in developed and developing countries.

Within PCI research, it has been long established that consumers distinguish between the image that they have of their domestic and foreign products (Morello, 1984; Nebenzahl, Jaffe, \& Usunier, 2003; Papadopoulos, Heslop, \& Bamossy, 1990). There are effectively two PCI images: one for the home country of respondents and one for other, foreign countries (see, for example, Dimitrovic \& Vida, 2010; Papadopoulos \& Heslop, 2003; Verlegh \& Steenkamp, 1999). This leads us to the first element of our conceptual framework of $\mathrm{PCI}$ relationships: there are two separate PCIs, namely Home Product Country Image (HPCI) and Foreign Product Country Image (FPCI). These two elements are shown in Fig. 1 along with the other four components of the conceptual framework of this paper.

\subsection{PCI in developed and developing countries}

By definition, the distinction between developed and developing countries is essentially economic and wealth-related (UNCTAD, 2012; World Bank, 2010). We explain the number and choice of 


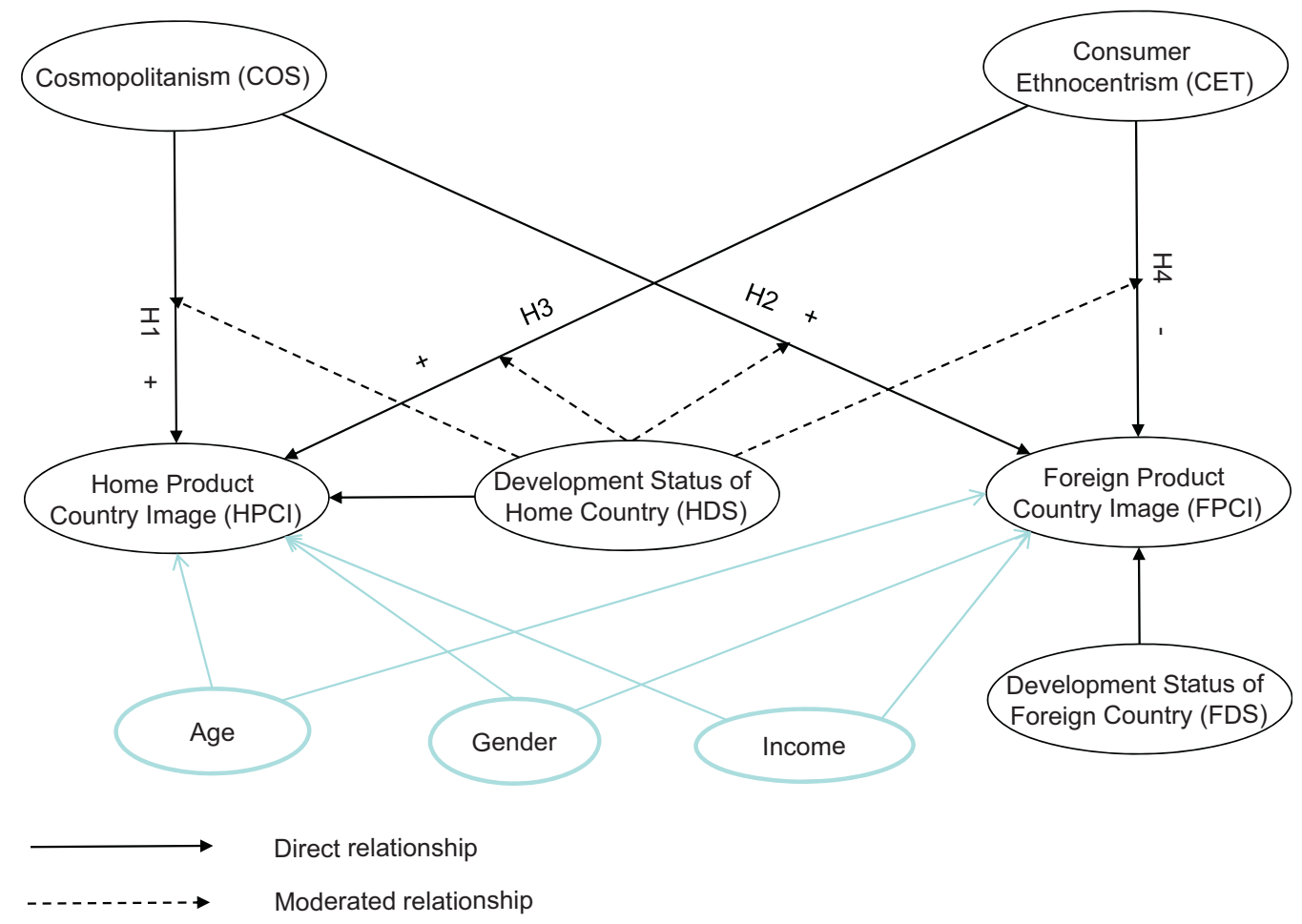

Fig. 1. A model of product country images: developing versus developed.

countries used in our research in the Methodology section. Using a Chinese sample only, Zhao (1996) demonstrated that country economic development status was a significant factor influencing purchasing behavior. More generally, PCI studies have mainly surveyed developed countries: Dinnie reviewed 40 research papers and identified only 7 that included research samples from developing countries (Dinnie, 2004: Appendix 2). Roth and Diamantopoulos surveyed 30 papers of which only 5 contained samples from developing countries (Roth \& Diamantopoulos, 2009: Table 2). Sharma comments that "very few studies explore the perceptions of consumers in emerging markets about products made in other emerging markets" (Sharma, 2011, p. 286). Some papers have included the economy of a country as part of its $\mathrm{PCI}$ (Allred, Chakraborty, \& Miller, 1999; Martin \& Eroglu, 1993) but have not investigated its economic development status as a separate construct. Given the widely used distinction in economic and business analysis between developed and developing countries, it is perhaps surprising that there has been so little comparative research in this area.

With regard to the differences between $\mathrm{PCI}$ in developed and developing countries, it has been argued that developed countries are likely to have a more favorable image for technically complex and innovative products, leading to issues of risk aversion versus aspiration among customers in developing countries (Souiden, Pons, \& Kayrand, 2011). This is consistent with other research suggesting that products from developed countries have higher quality than those from developing countries (Pappu et al., 2007; Usunier \& Cestre, 2008). However, the many differences between developed and developing countries in socio-economic, demographic and other factors may lead to more complex differences in the PCIs of developed and developing countries (Batra, 1997; Cui \& Liu, 2001). This lack of conclusive evidence is consistent with other research on the related concept of Country-of-Origin (COO) in developed and developing countries. Some studies show consumers in developing countries have a clear preference for foreign goods (Ettenson, 1993; Wang \& Yang, 2008) whereas other studies in developing countries show more complex differences based on such areas as whether the product is purchased for personal or public consumption (Hu, Li, Xie, \& Zhou, 2008), perceptions about home country products (Kinra, 2006; Li, Fu, \& Murray, 1997) and the degree of global brand localization over time (Jin, Chansarkar, \& Kondap, 2006). From the existing evidence, it is not clear in general whether the differences between the PCIs of developed and developing countries are greater than the differences between individual countries. However, this conclusion does not necessarily apply to the antecedents of PCI.

\subsection{Antecedents to product country image}

For this research, we have chosen two antecedents, namely Cosmopolitanism (COS) and Consumer Ethnocentrism (CET), for two reasons: first, because they relate to globalization strategy, which remains a topic of significant interest both academically and managerially (Dimitrovic \& Vida, 2010; Dimofte, Johansson, \& Bagozzi, 2010; Shimp \& Sharma, 1987); second, because previous research studies, though not necessarily from the perspective of country development status, provide a useful benchmark for this paper (see for example, Cleveland et al., 2009; Kaynak \& Kara, 2002; Klein et al., 2006; Sharma, 2011). From the perspective of the increased integration and globalization of consumer purchasing intentions, COS supports greater homogeneity while CET is more likely to be linked with greater heterogeneity (Cleveland et al., 2009; Riefler, Diamantopoulos, \& Siguaw, 2012; Skrbis, Kendall, \& Woodward, 2004).

\subsection{Cosmopolitanism in developed and developing countries}

COS has been used to describe a tendency of individuals to regard themselves as world citizens rather than as citizens of a specific country (Riefler \& Diamantopoulos, 2009). It has also been described as "a conscious openness to the world and its cultural differences” (Skrbis et al., 2004, p. 117). We adopt this latter 
definition in this paper which addresses the important distinction between COS and globalization (Riefler et al., 2012). World communications and the culture-shaping values of world media support COS in both developed and developing countries (Cannon \& Yaprak, 2002; Craig \& Douglas, 2006; Hannerz, 1990).

While there is evidence to suggest that consumers from developed countries have unfavorable perceptions of products imported from developing countries (Papadopoulos et al., 1990), such perceptions have changed as a result of the increased lowcost manufacturing in developing markets (Chao, 1993). Consumers with a cosmopolitan perspective from developed markets may regard such products as being domestic brands or, alternatively, favorably regard foreign country brands because they may carry a domestic brand name or association (Cannon \& Yaprak, 2002; Steenkamp \& de Jong, 2010).

For consumers with a cosmopolitan perspective from developing countries, the evidence shows that they prefer products made in developed countries (Kinra, 2006; Strizhakova, Coulter, \& Price, 2008). However, it does not necessarily follow that they will have the same view of domestic brands. It has been argued (Batra, 1997) that the past history of the monopolistic, state-owned manufacturers in developing countries means that domestic developing country products will not be so highly regarded as those from developed countries. However, the past ten years has changed such perceptions for three reasons: lower trade barriers, more global branding and more outsourcing of manufacturing to developing markets (Sharma, Mathur, \& Dhawan, 2008).

With regard to home product country image (HPCI), the evidence and arguments above on COS lead to different hypotheses for developing and developed countries. From a cosmopolitan perspective, developing country consumers may not regard their domestic brands as delivering high status or wealth (Jaffe \& Nebenzahl, 2006; Strizhakova et al., 2008). However this does not mean that they have a low image of their domestic brands, especially if they have been consuming them for many years and they offer better value for money (Kinra, 2006) or they are seen as being both global and local (Alden, Kelly, Riefler, Lee, \& Soutar, 2013). Conversely, consumers from developing countries may buy cheap local brands for private consumption and more expensive foreign brands for public consumption (Hu et al., 2008). Hence, the relationship between COS and home product country image among consumers from developing countries may contain two opposing aspects of images. In this sense, COS for developing country consumers may not be linked as strongly and clearly with their home product country image as with their clearer and simpler perception of foreign product country image (Chen, 2009).

Developed country consumers with cosmopolitan perceptions will see their domestic brands as part of their range of products for purchase: they may differentiate between foreign and domestic brands but will engage both with "a conscious openness to the world and to cultural differences" with regard to both home country and foreign products (Skrbis et al., 2004, p. 117). Specifically, they will not necessarily regard foreign products as being inherently more attractive (Sharma, Shimp, \& Shin, 1995). In this sense, consumers from developed countries with a cosmopolitan outlook will have a stronger relationship with their home country image than those from developing countries (Alden et al., 2013). In other words, country development status of the consumer moderates the relationship between cosmopolitanism and home PCI. Hence, for differing but related reasons, we argue that:

H1. Cosmopolitanism is positively related to Home PCI in both developed and developing countries with the relationship being stronger in developed countries than developing countries.
We turn next to foreign product country image and its relationship with cosmopolitanism. By the very nature of COS, consumers from both developing countries and developed countries may consciously decide to consume products originating from cultures other than their own (Caldwell, Blackwell, \& Tulloch, 2006). However, for consumers from developing markets, there is some evidence that they may regard products from developed markets as an indication of their higher status, wealth and lifestyle and, in this sense, the possession of such products allows them to demonstrate that they are more cosmopolitan (Ettenson, 1993; Ghose \& Lowengart, 2001; Tse, Belk, \& Zhou, 1989). This suggests a strong relationship between COS and foreign product country image of consumers from developing countries.

By contrast, there is some evidence that people from developed markets may perceive themselves as being less provincial and more international (Hannerz, 1990). They are likely to be openminded and interested in other cultures (Skrbis et al., 2004). They also have the wealth and are willing to travel to experience other cultures (Cannon \& Yaprak, 2002). They may even wish to interact with other cultures as a result of their increased wealth and opportunity (Alden et al., 2013). In addition, such consumers from developed countries may be also less concerned about material needs and have broader horizons (Cleveland et al., 2009) and therefore be less concerned with a foreign product country image. Hence, COS may be more closely linked to foreign country image (FPCI) for consumers from developing countries than developed countries. In other words, country development status of the consumer moderates the relationship between cosmopolitanism and foreign PCI. Hence we propose that:

H2. Cosmopolitanism is positively related to Foreign PCI in both developed and developing countries with the relationship being stronger in developing countries than developed countries.

\subsection{Consumer ethnocentrism in developed and developing countries}

Consumer ethnocentrism (CET) is defined as the beliefs held by consumers about the appropriateness and morality of purchasing home-made products and the rejection of foreign-made products (Shimp \& Sharma, 1987, p. 280). CET is rooted in three elements of consumer behavior: cognitive, affective and normative (Dimitrovic \& Vida, 2010). Highly ethnocentric consumers refuse to buy products and services that are imported from foreign countries. From this definition, it follows that CET is likely to contrast with COS (Cleveland et al., 2009; Vida \& Reardon, 2008). This is supported from research in developed countries (Baughn \& Yaprak, 1996; Sharma et al., 1995). However, other research in developing countries has suggested that the relationship is non-significant and that the two constructs are distinct (Suh \& Kwon, 2002; Vida \& Reardon, 2008). According to these findings, it is possible for consumers in developing countries to be both patriotic about the home country and curious about foreign cultures (Strizhakova et al., 2008).

By definition, consumers with strong CET tend to have a more favorable perception of domestic than foreign products (Ahmed \& d'Astous, 2001; Kipnis et al., 2012; Samiee, 1994; Wang \& Chen, 2004). In both developed and developing countries, there is a preference in such countries for products from the home country among consumers with strong CET (Bilkey \& Nes, 1982; Samiee, 1994; Spillan \& Harcar, 2012). For consumers from developed countries, this may be extended to products from countries with a similar cultural background (Lantz \& Loeb, 1996; Watson \& Wright, 2000). Nevertheless, consumers in developed countries tend to have a more favorable perception of domestic than foreign products (Ahmed \& d'Astous, 2001; Samiee, 1994; Wang \& Chen, 2004). Moreover, the evidence suggests in developed countries 
that CET is particularly strong among those who feel that they are threatened by foreign competitors from imports taking away their employment and destroying their culture (Shimp \& Sharma, 1987; Vida \& Reardon, 2008).

In developing countries where consumer ethnocentrism exists, consumers may also feel similarly threatened by large multinationals that destroy their culture (Alden et al., 2013). While there is some evidence that the level of CET in such countries will vary depending on the extent to which such consumers have been affected by globalization (Reardon, Miller, Vida, \& Kim, 2005; Strizhakova et al., 2008; Wang \& Chen, 2004), consumers in developing countries, do not necessarily have the same degree of attachment toward domestic products (e.g., Batra, Venkatram, Alden, Steenkamp, \& Ramachander, 2000; Li et al., 1997; Ueltschy, 1998). For example, Wang and Chen (2004) show that ethnocentric consumers in developing countries may positively evaluate the quality of imports to some extent if they are perceived as being associated with a country which is highly industrialized or economically developed. Consumers in developing countries will prefer foreign products because of their good quality and novelty but this benign effect will lessen as an economy becomes more developed (Shankarmahesh, 2006), thus suggesting that developing countries in the earlier stages of economic development will have lower CET than developed countries. Hence, we argue that:

H3. Consumer ethnocentrism is positively related to Home PCI in both developed and developing countries with the relationship being stronger in developed countries than developing countries.

Turning to the converse of the above, the CET evidence with regard to foreign products suggests that they will have a negative relationship for the same reasoning as above (Riefler \& Diamantopoulos, 2009; Shimp \& Sharma, 1987). This will apply to a greater or lesser extent to both developed and developing countries.

While consumers in some developing markets may also be threatened by employment substitution from multinationals changing their production sourcing, the increased use of manufacturing and services outsourcing by the same multinationals from developed to developing countries may be seen as making a contribution to the wealth of developing countries (Reardon et al., 2005; Sharma et al., 2008; Wang \& Chen, 2004). For example, it is well established that Chinese manufacturing and Indian software outsourcing have been sources of growth and increased wealth in these two developing countries (Mattoo \& Wunsch, 2004). Moreover, there is some evidence that developing countries have contained a higher percentage of counterfeits, replicas and unbranded products with the implication that global brands are the main source of knowledge about global products (Strizhakova et al., 2008). In this sense, developing countries have a more ambivalent relationship with CET and are able to distinguish between cultural openness and CET (Vida, Dmitrovic, \& Obadia, 2008; Vida \& Reardon, 2008). However, in the broader context of the threat to the quality of life and economic livelihood derived from foreign products (Shimp \& Sharma, 1987), consumers in developing countries with their lower levels of wealth and reliance on lower-value natural resource endowment (Maddison, 2013) may feel particularly threatened by foreign imports, particularly as they achieve greater economic growth (Shankarmahesh, 2006). For example, Indian agricultural workers and shopkeepers have blocked foreign companies from taking over their land for manufacturing and large retail stores (Corbridge \& Shah, 2013). Hence, we hypothesize:

H4. Consumer ethnocentrism is negatively related to Foreign PCI in both developed and developing countries with the relationship being stronger in developing than developed countries.

\section{Research method}

\subsection{Country selection}

For the purposes of this research, we adopted an economic and wealth-related definition to categorize developed and developing countries (World Bank, 2010). We used this data to identify France, the United Kingdom and the United States of America as being the developed countries in our sample. We used the same data to categorize developing countries.

Given that it is not possible to survey every developing country, we decided on two criteria: first, that we would include the two largest developing countries - China and India - and second that we would seek developing countries from every major continent. Thus, we have Turkey and Egypt from Europe/Middle East, two African countries - one small and one large, another mid-size from South East Asia and the largest country by population from South America. We considered including Eastern European countries but decided against this because they were no longer clearly developing countries in the sense used by the World Bank. Although there are major differences between these countries, we suggest that it is acceptable to group these as representing developing countries (Yip, 2000). With regard to the balance between developed and developing countries, we chose three developed and eight developing countries because this is broadly the proportion of developed to developing countries in OECD membership of developed to developing countries in the world (23\% versus $27 \%$ ).

\subsection{The most familiar foreign country approach}

For a variety of reasons associated with research methodology, sampling and statistical analysis, much of the product country research has been conducted using pre-selected countries (see, for example, Bilkey \& Nes, 1982; Papadopoulos \& Heslop, 2003; Pharr, 2005; Verlegh \& Steenkamp, 1999). From a cognitive, theoretical perspective, this has significant weaknesses. It assumes that respondents have both sufficient knowledge of the pre-selected foreign country and judge the foreign country to be important to them when making international purchasing decisions.

In a similar way to pre-selected country issues, much of the previous $\mathrm{PCI}$ and $\mathrm{COO}$ research has employed pre-selected products. For example, Aurier and Fort (2007) pre-selected cheese and canned meat; Auger, Devinney, Louviere, and Burke (2010) pre-selected AA batteries and athletic shoes; Sharma (2011) preselected cars. Again, there have been strong reasons associated with research methodology for such pre-selections. However, we have chosen to follow Samiee's (2010, p. 445) advice that research "must shift to developing a good understanding of the forest before proceeding to examine every tree" - meaning research at the country level before the product level.

Country familiarity has long been associated with product country image (d'Astous et al., 2008). Ahmed and d'Astous (2008) argued that consumers with a higher country familiarity tend to be more favorable in the evaluation of that country with respect to its products. Laroche, Papadopoulos, Heslop, and Mourali (2005), however, claim that regardless of consumer's product familiarity, country image is significantly related to product evaluation.

In other words, in existing studies which select a particular country in advance, their test of the impact of foreign country image is due to a combination of 'foreign country effect' and 'country familiarity effect', as stereotyping often arises from incomplete understanding of a particular country.

To overcome these problems, we have developed a new approach to country selection, which we call the 'most familiar foreign country.' First, we asked respondents to examine a list of 
only 18 countries (out of at least 140) with these countries accounting for 75 percent of the world's GDP. The purpose here was to ensure that respondents focused on the larger, more wellknown countries. We made the assumption that all respondents will at least be familiar with one significant foreign country. Second, we asked respondents to pick the country from this list with which they were 'most familiar.' The purpose here was to ensure that respondents had a specific country image when considering the repeated $\mathrm{PCI}$ image scaling questions that followed. We then asked respondents to rate their most familiar foreign country for product image data in the same way as they did for their home country.

By allowing consumer selecting the most familiar foreign countries from a relatively large pool of countries, we are able to test the "foreignness effect" instead of a combination of foreign and familiarity effect.

Another advantage of this approach over that of pre-selecting one particular country as the only foreign country of the study is that the image of that country may be 'fixed' in such a way that it may not be flexible enough to reflect the foreign country image at all (Laroche et al., 2005).

For example, Sharma (2011, p. 272), pre-selected a fictitious brand of car and pre-selected four countries USA, UK, China and India. We doubt whether UK respondents will have sufficient knowledge of Indian or Chinese car products to make any useful judgment on the PCI of India or China based on car products, let alone a view on whether India and China are important for such respondents when purchasing a car. The choices made are shown in Table 2.

\subsection{Sample}

We have used a sample of younger generation consumers in this research, age range from 18 to 45 years old. The reason is that the purpose of this research is to explore some aspects of globalization and this age group is most likely to be amenable to this topic and have the lowest barriers to international trade (Shukla, 2011). In addition, this segment contains hundreds of millions of people globally, and is particularly interesting to managers of multinational firms (Strizhakova et al., 2008).

Survey data for this research was then obtained from 2655 respondents in eleven countries. The developed countries were the USA $(n=345)$, France $(n=214)$ and the UK $(n=213)$. The developing countries were China $(n=264)$, Egypt $(n=261)$, India $(n=333)$, Brazil $(n=94)$, Malaysia $(n=304)$, Mauritius $(n=59)$, South Africa $(n=224)$ and Turkey $(n=345)$. The sample characteristics are shown in Table 1 . In every country, we used student university samples. They are mainly students from business schools. As it can be seen from Table 1, the sample contains a wide range of students from undergraduates to postgraduates. We have about one third of the sample are postgraduates. Most of them are MBA or EMBA students with several years' working experience before joining in the university. Participation was entirely voluntary. While there has been some criticism of student sampling, it was considered appropriate in this case as we met criteria established by prior scholars regarding when such samples are appropriate (e.g., Bello, Kwok, Radebaugh, Tung, \& Van Witteloostuijn, 2009). First, we were undertaking theory testing when relationships between magnitudes are being explored rather than absolute numbers (Calder, Philips, \& Tybout, 1981; ZeugnerRoth, Diamantopoulos, \& Montesinos, 2008), i.e. the core test is about the moderation effect of country development status. Our study therefore satisfies the internal validity criteria set by Bello et al. (2009) as fundamental issues regarding individual attitudes and perceptions are examined. Additionally, using student samples allowed us to gain relatively consistent samples across countries with respect to their relationships with our study variables (Hofstede, 1980). Finally, we argue that because university

Table 1

Sample profile.

\begin{tabular}{|c|c|c|c|c|c|c|c|c|c|c|c|c|}
\hline & \multirow[t]{2}{*}{ Total } & \multicolumn{3}{|c|}{ Developed countries } & \multicolumn{8}{|c|}{ Developing countries } \\
\hline & & France & UK & USA & China & Egypt & India & Brazil & Malaysia & Mauritius & South Africa & Turkey \\
\hline Sample size $(N)$ & 2655 & 214 & 213 & 345 & 264 & 261 & 333 & 94 & 304 & 59 & 224 & 345 \\
\hline \multicolumn{13}{|l|}{ Gender } \\
\hline Female & $45 \%$ & 45 & 45 & 51 & 52 & 54 & 21 & 43 & 62 & 54 & 25 & 46 \\
\hline Male & $55 \%$ & 55 & 55 & 49 & 48 & 46 & 79 & 57 & 38 & 46 & 75 & 54 \\
\hline \multicolumn{13}{|l|}{ Age } \\
\hline Under 24 & $69 \%$ & 62 & 86 & 76 & 92 & 100 & 46 & 57 & 55 & 88 & 3 & 95 \\
\hline $25-44$ & $31 \%$ & 38 & 14 & 24 & 8 & 0 & 54 & 43 & 45 & 12 & 97 & 5 \\
\hline \multicolumn{13}{|l|}{ Education } \\
\hline Undergraduate Year 1 & $19 \%$ & 27 & 24 & 4 & 19 & 19 & 3 & 21 & 7 & 76 & 1 & 56 \\
\hline Undergraduate Year 2 & $15 \%$ & 11 & 32 & 6 & 9 & 28 & 1 & 6 & 32 & 2 & 0 & 21 \\
\hline Undergraduate Year 3 & $18 \%$ & 25 & 14 & 61 & 14 & 22 & 1 & 14 & 15 & 2 & 1 & 2 \\
\hline Undergraduate Year 4 & $15 \%$ & 15 & 2 & 27 & 28 & 28 & 3 & 39 & 2 & 0 & 1 & 19 \\
\hline Postgraduate & $31 \%$ & 17 & 28 & 2 & 30 & 0 & 87 & 13 & 43 & 0 & 94 & 1 \\
\hline Other & $2 \%$ & 5 & 0 & 0 & 0 & 3 & 5 & 7 & 1 & 20 & 3 & 1 \\
\hline \multicolumn{13}{|l|}{ Household annual income } \\
\hline Up to $£ 1999$ & $16 \%$ & 11 & 9 & 4 & 26 & 6 & 16 & 15 & 52 & 29 & 3 & 12 \\
\hline$£ 2000-4999$ & $11 \%$ & 10 & 7 & 5 & 29 & 5 & 15 & 16 & 10 & 14 & 1 & 16 \\
\hline$£ 5000-9999$ & $14 \%$ & 11 & 10 & 10 & 21 & 7 & 27 & 18 & 15 & 31 & 1 & 14 \\
\hline$£ 10,000-19,999$ & $12 \%$ & 12 & 12 & 11 & 14 & 9 & 18 & 9 & 15 & 12 & 3 & 11 \\
\hline$£ 20,000-29,999$ & $9 \%$ & 11 & 13 & 14 & 2 & 11 & 7 & 12 & 3 & 3 & 7 & 12 \\
\hline$£ 30,000-39,999$ & $8 \%$ & 15 & 12 & 13 & 3 & 9 & 4 & 7 & 1 & 2 & 10 & 9 \\
\hline$£ 40,000-59,999$ & $9 \%$ & 17 & 15 & 12 & 1 & 8 & 2 & 6 & 2 & 0 & 25 & 9 \\
\hline$£ 60,000-99,999$ & $8 \%$ & 7 & 6 & 18 & 0 & 8 & 2 & 6 & 0 & 0 & 32 & 6 \\
\hline$£ 100,000$ or more & $8 \%$ & 1 & 11 & 11 & 2 & 16 & 4 & 11 & 1 & 3 & 16 & 6 \\
\hline Not disclosed & $5 \%$ & 5 & 5 & 2 & 2 & 21 & 5 & 1 & 1 & 6 & 2 & 6 \\
\hline \multicolumn{13}{|l|}{ Size of the family } \\
\hline 1-2 people & 15 & 43 & 11 & 20 & 6 & 6 & 6 & 21 & 9 & 3 & 43 & 5 \\
\hline $3-4$ & 53 & 42 & 48 & 50 & 72 & 64 & 26 & 64 & 24 & 61 & 42 & 69 \\
\hline 5 or more & 31 & 14 & 41 & 29 & 20 & 26 & 65 & 15 & 67 & 36 & 14 & 25 \\
\hline Not disclosed & 1 & 1 & 1 & 1 & 2 & 4 & 3 & 0 & 0 & 0 & 1 & 1 \\
\hline
\end{tabular}

Note: The statistical analysis that will control for Table 1 variables will come in a later draft. 
students are able to make those decisions investigated, the external validity criteria specified by Bello et al. (2009) is also satisfied. Lastly, the university students as a segment itself is relative large involving tens of millions of people with increasing purchasing power.

\subsection{Data collection}

All the questionnaires were in English except for France, China, Brazil and Turkey. For these latter countries, the questionnaire was translated into the national language by a local person and then back translated by a different native speaker to ensure the accuracy of the translation. In all cases including those in English, the questionnaires were adapted for the national country. For example, the Indian questionnaire in the English language referred to India as the home country and used Rupees to obtain the income data. The data collection was conducted between 2010 and 2011.

The students were each given a written questionnaire to complete in a classroom setting with the organizer ensuring that the lengthy questionnaire was understood and completed individually. The questionnaire was piloted among some 80 students in the U.K. and extensive adjustments made for comprehension, relevance and readability before the main survey above was undertaken in each country. The complete questionnaire used in each country began with questions about the country source of products with which students would be familiar. Importantly, every completed questionnaire was returned to the UK for individual scrutinizing before processing.

To minimize common method bias (Richardson, Simmering, \& Sturman, 2009), this study follows a filtering design with the steps recommended by Dillman (2007). Further, three remedies were adopted. First we used scales with different response formats (COS and CET Likert scale format, HPCI and FPCI Semantic Differential format). Second, we ran pilot testing using two separate questionnaires with different question orders to the same group of respondents (16 respondents). The results indicate that there was no bias due to the change of question order. Third, given that our dependent variables are product country images, we asked the respondents to rate their most familiar foreign country from an extensive list rather than imposing a particular country on them.
This can reduce the suspicion the respondents may have toward the purpose of the study and it makes it difficult for respondents to guess the possible outcome, thus reducing common method bias.

\subsection{Constructs and measurements}

All of the measurement items of the constructs are adapted from previous literature (Cleveland et al., 2009). Following previous research, we measure COS and CET using five point Likert scales ( 1 = "strongly disagree", 5 = "strongly agree", see Table 3). Measurements for COS are adapted from Cleveland et al. (2009). CET is measured by a simplified four-item version of the CETSCALE (Shimp \& Sharma, 1987) as employed by a number of previous studies (Batra et al., 2000; Cleveland et al., 2009; Klein, 2002).

Following previous research (Jin et al., 2006; Li et al., 1997; Okechuku \& Onyemah, 1999; Pappu et al., 2007), we employed a scale of product-country image developed originally by Roth and Romeo (1992). Both perceptions of home country product/brands and perceptions of foreign country product/brands or productcountry image were measured in 7-point semantic differential scale items. The respondents were first asked for their national identity (citizenship). Then they were asked about their perceptions regarding products/brands originating from their home country in terms of innovativeness, workmanship, quality, performance, etc. They were then asked to choose the country with which they were most familiar with from a list of 18 countries (see Table 2), as noted above. They were then asked about their perceptions regarding products/brands originated from the foreign country that they had selected. The descriptive statistics for these variables and the correlation matrix are shown in Table 3.

\subsection{Structured equation modeling}

For the structured equation modeling, we followed a process recommended by Hair, Black, Babin, and Anderson (2009) using AMOS 21 software. We present our results in two parts. First we examine the measurement properties of key constructs in Tables 4 and 5. We then use the structured equation modeling system to show the structural paths linking the hypotheses - see Table 6 .

Table 2

The most familiar foreign country: the countries chosen.

\begin{tabular}{|c|c|c|c|c|c|c|}
\hline & \multicolumn{6}{|c|}{ Home country development status and the most familiar country selected sample numbers and Frequency (percentage \%) } \\
\hline & $\begin{array}{l}\text { Number of people from } \\
\text { the developed countries } \\
\text { sample that chose... }\end{array}$ & (\%) & $\begin{array}{l}\text { Number of people from } \\
\text { the developing countries } \\
\text { sample that chose ... }\end{array}$ & $(\%)$ & $\begin{array}{l}\text { Number of people from } \\
\text { the total sample that chose ... }\end{array}$ & $(\%)$ \\
\hline \multicolumn{7}{|c|}{...As the most familiar foreign countries } \\
\hline ..USA & 192 & $(24.9)$ & 792 & $(42.1)$ & 954 & $(37)$ \\
\hline ...UK & 112 & $(14.5)$ & 220 & (11.7) & 332 & (12.5) \\
\hline ...Japan & 81 & (10.5) & 234 & (12.4) & 315 & (11.9) \\
\hline ...Germany & 56 & $(7.3)$ & 149 & (7.9) & 205 & $(7.7)$ \\
\hline ...China & 68 & $(8.8)$ & 110 & $(5.8)$ & 178 & (6.7) \\
\hline ...Italy & 57 & (7.4) & 76 & $(4.0)$ & 133 & $(5.0)$ \\
\hline ...France & 27 & (3.5) & 75 & $(4.0)$ & 102 & $(3.8)$ \\
\hline ...Spain & 73 & (9.5) & 27 & (1.4) & 100 & (3.8) \\
\hline ...Korea & 6 & $(.8)$ & 54 & $(2.9)$ & 60 & $(2.3)$ \\
\hline ...India & 23 & (3.0) & 31 & $(1.6)$ & 54 & $(2.0)$ \\
\hline ...Mexico & 35 & $(4.5)$ & 13 & $(.7)$ & 48 & $(1.8)$ \\
\hline ...Russia & 6 & $(.8)$ & 29 & $(1.5)$ & 35 & $(1.3)$ \\
\hline ...Brazil & 19 & $(2.5)$ & 6 & $(.4)$ & 24 & $(.9)$ \\
\hline ...Turkey & 6 & $(.8)$ & 13 & $(.7)$ & 20 & $(.8)$ \\
\hline ...South Africa & 3 & $(.4)$ & 17 & (.9) & 20 & $(.7)$ \\
\hline ...Malaysia & 4 & $(.5)$ & 16 & $(.8)$ & 19 & $(.7)$ \\
\hline ...Finland & 0 & $(.0)$ & 14 & $(.7)$ & 15 & $(.5)$ \\
\hline ...Egypt & 4 & $(.5)$ & 7 & $(.4)$ & 11 & $(.4)$ \\
\hline Total & 772 & $(100)$ & 1883 & $(100)$ & 2655 & $(100)$ \\
\hline
\end{tabular}


Table 3

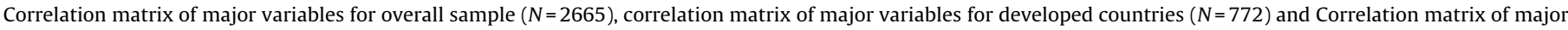
variables for developing countries $(N=1883)$.

\begin{tabular}{|c|c|c|c|c|c|c|c|}
\hline \multicolumn{8}{|c|}{ Correlation matrix of major variables for overall sample $(N=2665)$} \\
\hline & Mean & s.d. & INCOME & CET & $\cos$ & $\mathrm{HPCI}$ & FPCI \\
\hline INCOME & 4.37 & 2.51 & 1 & & & & \\
\hline CET & 2.86 & 1.22 & $-.11^{* *}$ & 1 & & & \\
\hline $\cos$ & 4.01 & .75 & $.13^{* *}$ & $-.14^{* *}$ & 1 & & \\
\hline HPCI & 4.10 & 1.31 & $.06^{* *}$ & .01 & $.07^{* *}$ & 1 & \\
\hline $\mathrm{FPCI}$ & 5.37 & 1.26 & -.00 & $-.12^{* *}$ & $.13^{* *}$ & $-.06^{* *}$ & 1 \\
\hline \multicolumn{8}{|c|}{ Correlation matrix of major variables for developed countries $(N=772)$} \\
\hline & Mean & s.d. & INCOME & CET & $\cos$ & $\mathrm{HPCI}$ & FPCI \\
\hline INCOME & 5.29 & 1.27 & 1 & & & & \\
\hline CET & 2.41 & 1.18 & .01 & 1 & & & \\
\hline $\cos$ & 4.21 & .73 & .04 & $-.14^{* * *}$ & 1 & & \\
\hline $\mathrm{HPCI}$ & 4.78 & 1.15 & .03 & $.10^{* * *}$ & $.07^{*}$ & 1 & \\
\hline FPCI & 5.13 & 1.29 & -.04 & $-.10^{* * *}$ & $.10^{*}$ & .05 & 1 \\
\hline \multicolumn{8}{|c|}{ Correlation matrix of major variables for developing countries $(N=1883)$} \\
\hline & Mean & s.d. & INCOME & CET & $\cos$ & HPCI & FPCI \\
\hline INCOME & 3.98 & 2.56 & 1 & & & & \\
\hline CET & 3.05 & 1.19 & $-.08^{* *}$ & 1 & & & \\
\hline cos & 3.94 & .75 & $.11^{* *}$ & $-.08^{* *}$ & 1 & & \\
\hline HPCI & 3.83 & 1.27 & -.03 & $.10^{* *}$ & -.01 & 1 & \\
\hline $\mathrm{FPCI}$ & 5.48 & 1.23 & $.05^{*}$ & $-.17^{* *}$ & $.17^{* *}$ & $-.05^{*}$ & 1 \\
\hline
\end{tabular}

${ }^{*} P<.05$.

${ }^{* *} P<.01$.

\section{Research results}

\subsection{Measurement validity and reliability}

As recommended by Gerbing and Hamilton (1996), we used exploratory factor analysis (EFA) to identify poorly fitted items and then confirmatory factor analysis for further measurement purification. One item from the Cosmopolitanism construct was removed because it did not comply with the unidimensionality requirements.

To test the construct equivalence among our 11 countries, we conducted multi-group confirmatory factor analysis as suggested by Hair et al. (2009) using the maximum likelihood fitting procedure in Amos 21. We examined configural equivalence for the total sample and then did the same for each individual country data set. The results of the multiple group confirmatory analysis are shown in Tables 4 and 5 .

As it can be seen from Table 4, the baseline model for the entire data set yielded a very good fit to the data $\left(\chi^{2} / \mathrm{df}=4.19\right.$, RMSEA $=.035, \mathrm{NFI}=.98, \mathrm{CFI}=.99$ ). According to the cut-off criteria by Hair et al. (2009, p. 672), the models for each country sample demonstrate consistently good fit. All factor loadings were significant at $P<.01$ across all country models as well as the total sample. Furthermore, Table 5 shows that the composite

Table 4

Construct measurement.

\begin{tabular}{|c|c|c|c|}
\hline & $\begin{array}{l}\text { Standardized } \\
\text { loading }\end{array}$ & $\begin{array}{l}\text { Composite } \\
\text { reliability }\end{array}$ & $\begin{array}{l}\text { Average variance } \\
\text { extracted }\end{array}$ \\
\hline Consumer ethnocentrism (CET) & & .89 & .66 \\
\hline CET1: purchasing foreign-made products is un-(Country) & .698 & & \\
\hline $\begin{array}{l}\text { CET2: [Country people] should not buy foreign products because this cost [country] business } \\
\text { and cause unemployment }\end{array}$ & .854 & & \\
\hline CET3: a real [Country person] should always buy [country] made products & .852 & & \\
\hline CET4: it is not right to purchase foreign products & .834 & & \\
\hline Cosmopolitanism (COS) & & .92 & 69 \\
\hline COS1: I enjoy exchanging ideas with people from other cultures or countries. & .797 & & \\
\hline COS2: I am interested in learning more about people who live in other countries. & .855 & & \\
\hline COS3: I enjoy being with people from other countries to learn about their views and approaches. & .900 & & \\
\hline COS4: I like to observe people from other countries to see what I can learn from them. & .825 & & \\
\hline COS5: I like to learn about other ways of life. & .770 & & \\
\hline Perceptions of Domestic PCI (HPCI) & & .86 & .60 \\
\hline HPCI 1: reliable & .765 & & \\
\hline HPCI 2: innovative & .705 & & \\
\hline HPCI3: high quality & .852 & & \\
\hline HPCI4: good performance & .762 & & \\
\hline Perception of brands of the most familiar foreign country PCI & & .90 & 69 \\
\hline FPCI1: reliable & .822 & & \\
\hline FPCI2: innovative & .790 & & \\
\hline FPCI3: high quality & .881 & & \\
\hline FPCI4: good performance & .826 & & \\
\hline Model fit & \multicolumn{3}{|c|}{$\begin{array}{l}\chi^{2}=473.2, \mathrm{df}=113, \chi^{2} / \mathrm{df}=4.19 \mathrm{RMSEA}=.035 \\
\mathrm{NFI}=.98, \mathrm{CFI}=.99, \mathrm{RFI}=.98, \mathrm{TLI}=.98, \mathrm{IFI}=.99\end{array}$} \\
\hline
\end{tabular}

Please cite this article in press as: Jin, Z., et al. The relationship between consumer ethnocentrism, cosmopolitanism and product country image among younger generation consumers: The moderating role of country development status. International Business Review (2014), http://dx.doi.org/10.1016/j.ibusrev.2014.08.010 
Table 5

Confirmatory factor analysis: developing versus developed countries.

\begin{tabular}{|c|c|c|c|}
\hline & \multicolumn{2}{|c|}{ Developed countries } & \multirow{2}{*}{$\begin{array}{l}\text { Developing countries } \\
\qquad(N=1883)\end{array}$} \\
\hline & $(N=2655)$ & $(N=772)$ & \\
\hline \multicolumn{4}{|c|}{ Factor loadings } \\
\hline \multicolumn{4}{|c|}{ CET } \\
\hline CET1 & .698 & .781 & 651 \\
\hline CET2 & .854 & .844 & .851 \\
\hline CET3 & .852 & .877 & .831 \\
\hline CET4 & .834 & .824 & .825 \\
\hline \multicolumn{4}{|l|}{$\cos$} \\
\hline $\cos 1$ & .797 & .778 & .760 \\
\hline $\cos 2$ & .855 & .894 & .835 \\
\hline $\cos 3$ & .900 & .920 & .889 \\
\hline $\cos 4$ & .825 & .831 & .818 \\
\hline cos5 & .770 & .761 & .755 \\
\hline \multicolumn{4}{|l|}{$\mathrm{HPCI}$} \\
\hline HPCI1 & .765 & .788 & .741 \\
\hline $\mathrm{HPCl} 2$ & .705 & .629 & .686 \\
\hline HPCI3 & .852 & .832 & .835 \\
\hline HPCI4 & .762 & .726 & .750 \\
\hline \multicolumn{4}{|l|}{ FPCI } \\
\hline FPCI 1 & .822 & .827 & .820 \\
\hline FPCI 2 & .790 & .777 & .792 \\
\hline FPCI3 & .881 & .860 & .888 \\
\hline FPCI4 & .826 & .838 & .818 \\
\hline \multicolumn{4}{|c|}{ Composite reliability } \\
\hline CET & .89 & .90 & .87 \\
\hline $\cos$ & .92 & .92 & .91 \\
\hline HPCI & .86 & .83 & .84 \\
\hline FPCI & .90 & .90 & .90 \\
\hline \multicolumn{4}{|c|}{ Average variance extracted } \\
\hline CET & .66 & .69 & .63 \\
\hline $\cos$ & .69 & .70 & .66 \\
\hline HPCI & .60 & .56 & .57 \\
\hline FPCI & .69 & .68 & .69 \\
\hline \multicolumn{4}{|c|}{ Fitness index } \\
\hline$\chi^{2}$ & 473.2 & 235.4 & 396.5 \\
\hline Df & 113 & 113 & 113 \\
\hline$\chi^{2} / \mathrm{df}$ & 4.19 & 2.08 & 3.51 \\
\hline RMSEA & .04 & .04 & .04 \\
\hline NFI & .98 & .97 & .98 \\
\hline CFI & .99 & .98 & .98 \\
\hline RFI & .98 & .96 & .97 \\
\hline IFI & .99 & .98 & .98 \\
\hline TLI & .98 & .98 & .98 \\
\hline
\end{tabular}

Note: We have also done a confirmatory factor analysis across individual nations. This has been excluded for reasons of word limitation but is available from the authors.

reliability for all exceeded the recommended threshold value of .70 (Nunnally, 1978). This is consistent across all countries as well as the entire data set. The average variance extracted (AVE) for the measures was .6 or above, exceeding the value .5 as recommended by Dillon and Goldstein (1984).
We also carried out a discriminate validity test as recommended by Fornell and Larcker (1981). AVE statistics for each latent variable are compared with the value of the shared variance of the latent variable with other latent variables. For all the variables in this study and for each country data set, no correlation exceeds the square root of the average variance extracted. Therefore the discriminate validity of the constructs holds and also indicates configural invariance across the 11 country data sets.

We further tested metric invariance and scalar process as recommended by Byrne (2010). Similar to Cleveland et al.'s (2009) eight country study, only partial metric invariance and partial scalar invariance are achieved. Given that the study has 11 different country data sets, this is as expected (Cleveland et al., 2009). This is not ideal, but as suggested by Cleveland et al. (2009), with a large number of country comparisons, partial metric invariance is more realistic than the ideal case of full metric invariance. This is an acceptable assumption as recommended in the existing literature (Byrne, Shavelson, \& Muthen, 1989; Steenkamp \& Baumgartner, 1998).

Furthermore, it would be unrealistic to do a pairwise comparison on a country-by-country basis $(11 \times 10 / 2=55$ scenarios). We therefore pool developed countries (USA, UK, and France) and developing countries (Brazil, China, Egypt, India, Malaysia, Mauritius, South Africa, Turkey) into two sub-data sets. A multiple group confirmatory analysis following the above procedure was conducted. The results are presented in Table 5. As can be seen from Table 5, configural invariance and discriminate validity hold for both data sets, and partial metric invariance and scalar invariance are achieved, consistent with recommendations from Vandenberg and Lance (2000) and Schmitt and Kuljanin (2008).

\subsection{Hypothesis testing}

To test the proposed hypotheses, we conducted multiple group analysis on the two sub-data sets (developing country sample versus developed country sample) following the procedure recommended by Byrne (2010) for moderation variables.

The results of the test are presented in Table 6. The first part of all hypotheses was tested using path coefficient analysis. The second part of the four hypotheses required testing the differences in the magnitude of effects between consumers from developed and developing countries. We used a series of comparisons between the unconstrained model and models in which only one structural path at a time was set to be equal between the two sample sets. Age, gender, and household income were used as control variables.

It can be seen from Table 6 that $\mathrm{H} 1$ is partially supported, indicating that cosmopolitanism is positively related to home product country image for developed countries (Beta $=.085$,

Table 6

Results of structural model.

\begin{tabular}{|c|c|c|c|c|c|c|c|c|}
\hline \multirow[t]{2}{*}{ Hypotheses } & \multirow{2}{*}{$\begin{array}{l}\text { Constructs paths or } \\
\text { moderation variables }\end{array}$} & \multirow{2}{*}{$\begin{array}{l}\text { Expected sign or } \\
\text { moderation effect }\end{array}$} & \multicolumn{3}{|c|}{ Developed countries } & \multicolumn{3}{|c|}{ Developing countries } \\
\hline & & & Beta & $P$-values & Support & Beta & $P$-values & Support \\
\hline $\begin{array}{l}\mathrm{H} 1 \text { : } \mathrm{COS} \text { is positively related to } \mathrm{HPCI} \text { with the } \\
\text { relationship being stronger in developed } \\
\text { countries than developing countries. }\end{array}$ & $\begin{array}{l}\mathrm{COS} \rightarrow \mathrm{HPCI} \\
\mathrm{HDS}\end{array}$ & $\begin{array}{l}+ \\
\text { Yes }\end{array}$ & \multicolumn{6}{|c|}{ Supported $\left(\Delta \chi^{2}(1)=4.362, P=.037<.05\right)$} \\
\hline $\begin{array}{l}\mathrm{H} 2 \text { : } \mathrm{COS} \text { is positively related to } \mathrm{FPCI} \text { with the } \\
\text { relationship being stronger in developing } \\
\text { countries than developed countries. }\end{array}$ & $\begin{array}{l}\mathrm{COS} \rightarrow \mathrm{FPCI} \\
\mathrm{HDS}\end{array}$ & $\begin{array}{l}+ \\
\text { Yes }\end{array}$ & \multicolumn{6}{|c|}{ Not supported $\left(\Delta \chi^{2}(1)=.993, P=.319\right)$} \\
\hline $\begin{array}{l}\text { H3: CET is positively related to } \mathrm{HPCI} \text { with the } \\
\text { relationship being stronger in developed } \\
\text { countries than developing countries. }\end{array}$ & $\begin{array}{l}\mathrm{CET} \rightarrow \mathrm{HPCI} \\
\mathrm{HDS}\end{array}$ & $\begin{array}{l}+ \\
\text { Yes }\end{array}$ & \multicolumn{6}{|c|}{ NOT supported $\left(\Delta \chi^{2}(1)=.855, P=.355\right)$} \\
\hline $\begin{array}{l}\text { H4: CET is negatively related to FPCI with the } \\
\text { relationship being stronger in developing } \\
\text { countries than developed countries. }\end{array}$ & $\begin{array}{l}\mathrm{CET} \rightarrow \mathrm{FPCI} \\
\mathrm{HDS}\end{array}$ & $\begin{array}{l}- \\
\text { Yes }\end{array}$ & \multicolumn{6}{|c|}{ Supported $\left(\Delta \chi^{2}(1)=5.107, P=.026<.05\right)$} \\
\hline
\end{tabular}


$P=.04$ ) but not for developing countries (Beta $=-.016, P=.530$ ). For $\mathrm{H} 1$ that the relationship between COS and $\mathrm{HPCI}$ is stronger for developed countries than for developing countries was supported $\left(\Delta \chi^{2}(1)=4.362, P=.037<.05\right)$.

For $\mathrm{H} 2$, it is found that cosmopolitanism is positively related to the most familiar foreign country product image for both developed (Beta $=.099, P=.09$ ) and developing countries (Beta $=.151, P=.000)$. While the relationship is stronger for developing countries than for developed countries in the path coefficient as expected, the difference in magnitude of the two path coefficients is not statistically significant $\left(\Delta \chi^{2}(1)=.993, P=.319\right)$. Therefore the moderation effect of country development status to the relationship between COS and FPCI is not supported.

We found similar results for $\mathrm{H} 3$. As it can be seen from Table 6 , CET is positively related to the home country product image for both developed and developing countries. However, we found almost no difference in the latitude of such relationship (Betas $=.104$ and .121 respectively, $\Delta \chi^{2}(1)=.855, P=.319$ ).

For $\mathrm{H} 4$, it was found that CET is negatively related to $\mathrm{FPCI}$ significant for developing countries (Beta $=-.146, P=.000$ ) but not significant for developed countries (Beta $=-.059, P=.126$ ). It indicates clearly a stronger relationship between CET and FPCI for developing countries as assumed $\left(\Delta \chi^{2}(1)=5.107, P=.026<.05\right)$.

To summarize, we found that country development status moderates the relationships between COS and $\mathrm{HPCI}$, and CET and FPCI. However, we did not find the moderation effects of country development status for the relationships between COS and FPCI, CET and HPCI.

\section{Discussion and conceptual contribution}

Over the last two decades, there has been growing interest in research into the difference of the $\mathrm{PCI}$ effect between developed countries and developing countries. However, most of this research has been mainly focused on a comparison of one developed country with another from a developing country (e.g., Jin et al., 2006; Shukla, 2011). Very few papers extend the research into multiple country settings (Cleveland et al., 2009; Sharma, 2011) and for younger consumers (Shukla, 2011). To remedy this gap, this paper has employed a sample from three developed countries and eight developing countries under 45 year old, with two thirds of the sample under 25 years of age. Controlling further three demographic variables such as age, household income and gender, the results taken overall from Table 6 suggest that there are significant differences in PCI between these two country groups. This new finding alone suggests that earlier PCI data may need to be re-considered in the context of such a distinction.

Our findings reveal a clearer picture of the differences in product country images between consumers from developed countries and those from developing countries. It rejects the often implicit assumptions in some earlier research that PCI perceptions are similar for consumers in both developed and developing countries (Batra, 1997; Cui \& Liu, 2001). Our study supports recent attempts by scholars to explore differences in consumer perceptions of PCI effects between these two groups of countries (Sharma, 2011; Shukla, 2011).

Exploring these differences in more depth, we found that COS and its relationship with home product country image and foreign product country image depends on whether consumers are from developed or developing countries ( $\mathrm{H} 1$ and $\mathrm{H} 2$ ). COS is positively related to HPCI for consumers from developed countries. This is consistent with the existing literature (Shukla, 2011). Although $\mathrm{COS}$ is not positively related to HPCI for consumers from developing countries, it is not negatively related to HPCI either, which seems to contradict some literature (Li et al., 1997). It can be argued that with increased globalization and economic development, those consumers high in cosmopolitanism from developing countries may have realized that home products/ brands are becoming increasingly competitive if not yet equal to products/brands from more developed countries.

Interestingly, COS is positively related to $\mathrm{FPCI}$ for younger consumers from both developed countries and developing countries. In other words, consumers who are high in COS prefer imported goods, irrespective of whether they are from developed or developing countries. This is consistent with earlier research (Kinra, 2006; Strizhakova et al., 2008) but goes further in suggesting that there is little difference, from a COS perspective, between developed and developing countries. This evidence has implications for globalization theory. It was obtained from a COS perspective, which is more international by definition. Moreover, it was obtained from a younger age group who may be more open to other cultures. However, it challenges the globalization theory that country differences make global product and marketing standardization too difficult to achieve (Ghemawat \& Ghadar, 2000; Ghemawat, 2001; Rugman \& Verbeke, 2003).

An interesting picture of CET is revealed from our study (H3 and H4). First of all, CET is positively related to HPCI. This is consistent with findings from existing literature (Kaynak \& Kara, 2002; Spillan \& Harcar, 2012). However, by comparing the two different groups of consumers, we are able to provide evidence for the first time that there is no difference in the magnitude of this effect between younger consumers from developed and developing countries. Second, high CET consumers tend to have a more negative image toward imported goods within both developed and developing countries, but the relationship has a higher magnitude among younger consumers from developing countries. This is consistent with previous research findings regarding the negative relationship between the two variables (Batra et al., 2000; Li et al., 1997; Sharma et al., 2008; Ueltschy, 1998).

Shukla (2011) called for more research into CET for young people who tend to accept global trends more quickly than older people. Indeed, Shankarmahesh's (2006) review of literature suggested that younger, better educated people generally tend to be less ethnocentric. Our results support this in principle, but revealed further the difference between younger people from developed countries and developing countries in the effect of CET.

Our findings are different in the sense that we found the relationship between CET and foreign product country image for developed country younger consumers is negative but insignificant. This, we argue, is not contradictory with previous research (Shankarmahesh, 2006; Sharma et al., 1995), but enriches previous findings. Referring to Table 2 (Column 2), it can be seen that over $75 \%$ of younger respondents from developed countries select other developed countries as their most familiar foreign countries. This indicates that high ethnocentric young consumers from developed countries in general do not have negative feelings toward imported goods from other developed countries. However, the reverse is true for younger consumers from developing countries toward imported goods from other countries, including developed countries.

Arguably, this contradicts earlier research which showed that ethnocentric consumers in developing countries may positively evaluate the quality of imports from developed countries, at least to some extent, if they are perceived to be associated with a country that is highly industrialized or economically developed and has products that are likely to be high quality and novel (Batra et al., 2000; Wang \& Chen, 2004). Our findings show that, from a CET perspective, younger consumers from developing countries are both likely to select developed countries as their 'most familiar' and, at the same time, to have negative feelings about products from the same developed countries. The implication for globalization theory is that global standardization in production and 
marketing is not enough. This evidence suggests that localization is also highly desirable - perhaps even mandatory (Ghemawat, 2007).

Some commentators have argued that evidence from young people, especially students, cannot be generalized to the whole population (Reynolds, Simintiras, \& Diamantopoulos, 2003). We accept this but would respond that such young people are an important market segment themselves and hold the potential to become wealthy customers over time after their studies (Strizhakova et al., 2008).

In addition, some commentators go further with regard to $\mathrm{COO}$ and PCI research. Samiee (2011) argues that, "A challenge in CO studies is demonstrating that consumers ... actually care about where products come from and incorporate this information in purchase decisions. Bulik (2007), for example, notes that especially young consumers ... are inexperienced and do not know nor apparently care about where products come from." Samiee then quotes Bulik directly: "Consumers aren't sure where their favorite products come from - and may not even care. In an increasingly global world of brands and media, is a product's country of origin even relevant any more? The younger demographic seems to vote a fairly definitive no. p. 278" (Bulik, 2007).

The evidence from our research shows that younger consumers are aware of $\mathrm{PCI}$ issues and we suggest, by implication, of $\mathrm{COO}$ issues. Moreover, the evidence from this study suggests that the views of such younger people are moderated by CET and COS and by the economic development status of their own home countries.

More generally, the results revealed a complicated picture with regard to globalization strategy. Kipnis et al. (2012) concluded that consumers from developing countries favor foreign brands that also have local affiliations. Our findings concur with this but go further by providing evidence of the magnitude of such sentiment among younger consumers. Younger consumers in developed countries with high CET accept imported goods more readily than their counterparts in developing countries. The reason would appear to be that international companies tend to project a distinguished and often superior image compared to local firms in both developed and developing countries. Our evidence shows that these feelings are stronger among developing countries than developed countries. Our findings suggest that such companies should not ignore the stronger feelings of the local affiliations linked to high CET consumers in developing countries. We suggest that it is particularly significant that this finding was present in our younger generation sample, who might have been expected to be more sympathetic to foreign companies (Strizhakova et al., 2008). This has significant implications for international companies from both developed countries and developing countries.

More broadly, our findings show that younger purchasers distinguish between the product image of their home country and that of foreign countries. This is consistent with the large body of previous research on PCI (see, for example, Baldauf, Cravens, Diamantopoulos, \& Zeugner-Roth, 2009; Papadopoulos \& Heslop, 1993, 2003; Pharr, 2005; Wang, Li, Barnes, \& Ahn, 2012). This evidence is important because it shows our new research methodology relating to the 'most familiar' foreign country and the student-based sample produces results that are consistent with previous research.

From a more generalized perspective, this paper has hypothesized a new model that incorporates the two constructs, HPCI and $\mathrm{FPCI}$, with two antecedent variables, COS and CET, and the two country groups, developed and developing countries - see Fig. 1. We acknowledge that this more complex model of purchasing will not depict all the factors involved in the purchasing decision for consumers from developed and developing countries. However, this empirical study offers significant new insights into some of the complex interactions involved in such purchasing decisions.

\section{Managerial relevance}

The insights obtained from this study have important implications for international marketers. First, younger generation consumers in different parts of the world are influenced by their home countries and their sense of belonging as evidenced by CET and COS with regard to $\mathrm{PCI}$ and purchasing. Thus, such managers can use CET and COS, to understand and explore differences in consumer perceptions between HPCI and FPCI. In particular, given that the relationship between these factors is not straightforward, our findings can assist international marketers to better understand market segmentation and positioning. This is important because a deeper knowledge of the consumer characteristics of different markets such as COS and CET will provide competitive advantages for such companies over their rivals (Riefler et al., 2012).

Although the empirical evidence is consistent with the longheld view that managers need to treat purchasing in developed countries differently from developing countries, it goes further than this. First, it suggests that the HPCI for products from developing countries is changing and becoming more positive among younger consumers. Such consumers with high COS from developing countries now have a higher image of their home countries. For international marketers, this means that they may need to reconsider how they present products from developing countries in their home markets.

Second, younger consumers with high COS both in developed and developing countries prefer imported goods. They find the distinction between developed and developing countries of low importance in the buying decision. The implication for international marketing is that global imagery is important for such consumers in terms of their buying decisions.

Third, the influence of consumer ethnocentrism on the purchasing decision among young consumers is strongly linked with HPCI for consumers from both developed and developing countries: arguably, this is predictable from the very nature of CET. What is not so predictable is that young consumers from developing countries with high CET feel more strongly about imported goods than those from developed countries. International marketers need to be sensitive to this distinction when promoting their products and services in developing countries. On the one hand, they need to position themselves clearly as 'international' brands. On the other hand, they need to demonstrate that they are committed to the local economy and societal well-being and therefore provide a sense of 'local' belonging and sentiment to overcome resistance from those consumers with high 'ethnocentric' tendencies. The key probably lies in how to strike the right balance between the two strategies.

\section{Concluding remarks}

In our study, we have embedded the development status of country origin (developing versus developed) of consumers for $\mathrm{HPCI}, \mathrm{FPCI}$. However, we have not explored fully the possible combinations of scenarios in formulating our hypotheses. Future research may take this into consideration. Future research might also consider other possible antecedents, such as Value Consciousness (Sharma, 2011). There is also a need to understand in more depth why and how the various antecedents interact with each other.

To sum up, we contribute to the literature in following new areas. First, we provide confirmatory evidence from a large sample of younger consumers in developed and developing countries where respondents are not forced into a pre-selected 'foreign country' that PCI differs between the perceptions of the home 
country and those of a foreign country. Second, we offer evidence that distinguishes between PCIs in developed and a range of developing countries. Third, we relate this evidence to consumer ethnocentrism and cosmopolitanism that may influence purchasing decisions, especially with regard to globalization strategy. Fourth, we provide the first evidence on four developing countries that have not previously been the subject of previous PCI studies, namely Egypt, Mauritius, South Africa, and Malaysia. Fifth, we have proposed and tested an embedded model that links country economic development status with $\mathrm{PCI}$ and consumer ethnocentrism and cosmopolitanism. Overall, we contend that we have made meaningful theoretical and empirical contributions to $\mathrm{PCI}$ research, while also establishing the groundwork for future studies.

There are certain methodological limitations to our study. As a result of the non-random nature of our sample, it is not possible to claim full external validity for our results. In addition, we recognize that we have a student sample, but we contend that students are consumers and, more generally, as discussed earlier, that our sample is appropriate for our study purpose in line with criteria set by prior researchers (e.g., Bello et al., 2009). Future studies could overcome this limitation by considering a more representative sample of national populations. For the country selection, we acknowledge that neither group can be fully representative of either 'developed' or 'developing' countries. Although the wide country variations within these two broad categories suggest greater generalizability than studies examining only one country in each category, future studies could cover a wider range of countries to extend the generalizability of our findings.

\section{Acknowledgements}

The authors would like to thank Prof. Richard Croucher and Prof. Marina Papanastasiou at Middlesex University, Prof. Kamel Mellahi at Warwick University, Dr Georgios Chrysochoidis at University of East Anglia, and Prof. David Ralston at Florida International University for their helpful comments and support for an earlier version of the paper. We would also like to thank Prof. Özlem Özkanlı at Ankara University, Mr. Paul Garneau and Dr. Yi Zhu at Middlesex University for their back translation of the Turkish, French, and Chinese versions of the questionnaire respectively. The authors are also grateful to the three anonymous reviewers for their comments on an earlier version of this paper.

\section{References}

Ahmed, S., \& d'Astous, A. (2001). Canadian consumers' perceptions of products made in newly industrializing east Asian countries. Journal of International Consumer Marketing, 11(1), 54-81.

Ahmed, S. A., \& d'Astous, A. (2008). Antecedents, moderators and dimensions of country-of-origin evaluations. International Marketing Review, 25(1), 75-106.

Alden, D., Kelly, J., Riefler, P., Lee, J., \& Soutar, G. (2013). The effect of global company animosity on global brand attitudes in emerging and developed markets: Does perceived value matter? Journal of International Marketing, 21(2), 17-38.

Allred, A., Chakraborty, G., \& Miller, S. (1999). Measuring images of developing countries: A scale development study. Journal of Euromarketing, 8(3), 29-49.

Auger, P., Devinney, T., Louviere, J., \& Burke, P. (2010). The importance of social product attributes in consumer purchasing decisions: A multi-country comparative study. International Business Review, 19(2), 140-159.

Aurier, P., \& Fort, F. (2007). The effects of perceived congruity between origin, brand and product on the purchase intention of a branded product of origin. Advances in Consumer Research - North American Conference Proceedings (pp. 3455-3463).

Baldauf, A., Cravens, K., Diamantopoulos, A., \& Zeugner-Roth, K. (2009). The impact of product-country image and marketing efforts on retailer-perceived brand equity: An empirical analysis. Journal of Retailing, 85(4), 437-452.

Batra, R. (1997). Executive insights: Marketing issues and challenges in transitional economies. Journal of International Marketing. 5(4), 95-114.

Batra, R., Venkatram, R., Alden, D., Steenkamp, J., \& Ramachander, S. (2000). Effects of brand local and nonlocal origin on consumer attitudes in developing countries. Journal of Consumer Psychology, 9(2), 83-85.
Baughn, C., \& Yaprak, A. (1996). Economic nationalism: Conceptual and empirical development. Political Psychology, 17(4), 759-778.

Bello, D., Kwok, L., Radebaugh, L., Tung, R., \& Van Witteloostuijn, A. (2009). From the Editors: Student samples in international business research. Journal of International Business Studies, 40(3), 361-364.

Bilkey, W. J., \& Nes, E. (1982). Country of origin effect on product evaluations. Journal of International Business Studies, 13(1), 89-99.

Birkinshaw, J., \& Morrison, A. (1995). Configurations of strategy and structure in subsidiaries of multinational corporations. Journal of International Business Studies, (4), 773-795.

Buckley, P., \& Ghauri, P. (2004). Globalisation, economic geography and the strategy of multinational enterprises. Journal of International Business Studies, 35(2), 8198.

Bulik, B. (2007). Ditch the flags; Kids don't care where you come from (cover story). Advertising Age, 78(23), 1-59.

Byrne, B. (2010). Structural equation modeling with AMOS: Basic concepts, applications, and programming (2nd ed.). New York: Routledge Academy.

Byrne, B., Shavelson, R., \& Muthen, B. (1989). Testing for the equivalence of factor covariance and mean structures: The issue of partial measurement invariance. Psychological Bulletin, 105(3), 456-466.

Calder, B., Philips, L., \& Tybout, A. (1981). Designing research for application. Journal of Consumer Research, 8(2), 197-207.

Caldwell, M., Blackwell, K., \& Tulloch, K. (2006). Cosmopolitanism as a consumer orientation: Replicating and extending prior research. Qualitative Market Research, (2), 126-139.

Cannon, H., \& Yaprak, A. (2002). Will the real-world citizen please stand up! The many faces of cosmopolitan consumer behavior Journal of International Marketing, 10(4), 30-52.

Cantwell, J. (1989). Technological innovation and multinational corporations. Oxford: Basil Blackwell.

Chabowski, B., Samiee, S., \& Hult, G. (2013). A bibliometric analysis of the global branding literature and a research agenda. Journal of International Business Studies, 44(6), 622-634

Chao, P. (1993). Partitioning country-of-origin effects: Consumer evaluations of a hybrid product. Journal of International Business Studies, 24(2), 291-306.

Chen, H. (2009). Effects of Country Variables on young generation's attitude towards American products: A multi-attribute perspective. Journal of Consumer Marketing, 26(3), 143-154

Cleveland, M., Laroche, M., \& Papadopoulos, N. (2009). Cosmopolitanism, consumer ethnocentrism, and materialism: An eight-country study of antecedents and outcomes. Journal of International Marketing, 17(1), 116-146.

Corbridge, S., \& Shah, A. (2013). Introduction: The underbelly of the Indian boom. Economics and Society, 42(3), 335-347.

Craig, C., \& Douglas, S. (2006). Beyond national culture: Implications of cultural dynamics for consumer research. International Marketing Review, 23(3), 322-342.

Cui, G., \& Liu, Q. (2001). Emerging market segments in a transitional economy: A study of urban consumers in China. Journal of International Marketing, 9(1), 84106.

d'Astous, A., Voss, F., Colbert, A., Carù, A., Caldwell, M., \& Courvoisier, F. (2008). ProductCountry images in the arts: A multi-country study. International Marketing Review 25(4), 379-403.

Dillman, D. (2007). Mail and Internet surveys: The tailored design method (2nd ed.). New York: John Wiley and Sons.

Dillon, W. R., \& Goldstein, M. (1984). Multivariate analysis: Methods and applications. New York: Wiley.

Dimitrovic, T., \& Vida, I. (2010). Consumer behaviour induced by product nationality: The evolution of the field and its theoretical antecedents. Transformations in Business and Economics, 9(1), 145-165.

Dimofte, C., Johansson, C., \& Bagozzi, R. (2010). Global brands in the United States: How consumer ethnicity mediates the global brand effect. Journal of International Marketing, 18(3), 81-106.

Dinnie, K. (2004). Country-of-Origin 1965-2004: A literature review. Journal of Consumer Behaviour, 3, 165-213.

Ettenson, R. (1993). Brand name and country of origin effects in the emerging market economies of Russia, Poland and Hungary. International Marketing Review, 10(5) $14-36$.

Fagerburg, J., \& Verspagen, B. (2002). Technology gaps, innovation diffusion and transformation: An evolutionary interpretation. Research Policy, 31(8/9), 12911304

Fornell, C., \& Larcker, D. (1981). Evaluating structural equation models with unobservable variables and measurement error. Journal of Marketing Research, 18(3), 39-50

Gerbing, D. \& Hamilton, J. (1996). Viability of exploratory factor analysis as a precursor to confirmatory factor analysis. Structural Equation Modeling, 3(1), 62-72.

Ghemawat, P. (2001). Distance still matters, the hard reality of global expansion. Harvard Business Review, 79(8), 137-147.

Ghemawat, P. (2007). Redefining global strategy: Crossing borders in a world where differences matter. Boston, MA: Harvard Business School Press.

Ghemawat, P., \& Ghadar, F. (2000). The dubious logic of global megamergers. Harvard Business Review, 78(4), 65-72.

Ghose, S., \& Lowengart, O. (2001). Perceptual positioning of international, national and private brands in a growing international market: An empirical study. Journal of Brand Management, 9(1), 45-62.

Hair, J., Black, W., Babin, J., \& Anderson, R. (2009). Multivariate data analysis (7th ed.) New Jersey: Prentice Hall.

Han, C. M., \& Terpstra, V. (1988). CIE effects for uni-national and bi-national products. Journal of International Business Studies, 19, 235-255. 
Hannerz, U. (1990). Cosmopolitans and locals in a world culture. Theory, Culture and Society, 7(2), 237-251.

Heslop, L. A., Papadopoulos, N., Dowdles, M., Wall, M., \& Compeau, D. (2004). Who controls the purse strings: A study of consumers' and retail buyers' reactions in an America's FTA environment. Journal of Business Research, 57(10), 1177-1188.

Hofstede, G. (1980). Culture's consequences: International differences in work-related values. Beverley Hills: Sage.

Hu, X., Li, L., Xie, C., \& Zhou, J. (2008). The effects of country-of-origin on Chinese consumers' wine purchasing behavior. Journal of Technology Management in China, 3(3), 292-306.

It's all in the eyes of the consumer (2006). Jaffe, E., \& Nebenzahl, I. (Eds.). National image and competitive advantage: The theory and practice of place branding (pp. 79-109). Herndon, VA: Copenhagen Business School Press.

Jin, Z., Chansarkar, B., \& Kondap, N. (2006). Brand origin in an emerging market: Perceptions of Indian consumers. The Asia Pacific Journal of Marketing and Logistics, 18(4), 283-302.

Kaynak, E., \& Kara, A. (2002). Consumer perceptions of foreign products: An analysis of product-country images and ethnocentrism. European Journal of Marketing, 36(7) 8), 928-949.

Kinra, N. (2006). The effect of country-of-origin on foreign brand names in the Indian market. Marketing Intelligence E' Planning, 24(1), 15-30.

Kipnis, E., Kubacki, K., Broderick, A., Siemieniako, D., \& Pisarenko, N. (2012). ‘They don’t want us to become them': Brand Local Integration and consumer ethnocentrism. Journal of Marketing Management, 28(7-8), 836-864.

Klein, J. (2002). Us versus them, or us versus everyone? Delineating consumer aversion to foreign goods. Journal of International Business Studies, 33(2), 345-363.

Klein, J. G., Ettenson, R., \& Krishnan, B. C. (2006). Extending the construct of consumer ethnocentrism: When foreign products are preferred. International Marketing Review, 23(3), 304-321.

Landes, D. (1998). The wealth and poverty of nations. London: Abacus.

Lantz, G., \& Loeb, S. (1996). Country of origin and ethnocentrism: An analysis of Canadian and American preferences using social identity theory. Advances in Consumer Research, 23, 374-378.

Laroche, M., Papadopoulos, N., Heslop, L., \& Mourali, M. (2005). The influence of country image structure on consumer evaluations of foreign products. International Marketing Review, 22(1), 96-115.

Leonidou, L., Palihawadana, D., \& Talias, M. (2007). British consumers' evaluations of US versus Chinese goods: A multi-level and multi-cue comparison. European Journal of Marketing, 41(7/8), 786-820.

Li, Z., Fu, S., \& Murray, L. (1997). Country and product images: The perceptions of consumers in the people's republic of China. Journal of International Consumer Marketing, 10(2), 115-139.

Maddison, A. (2013). Economic policy and progress in developing countries. London: Routledge.

Martin, I., \& Eroglu, S. (1993). Measuring a multi-dimensional construct: Country image. Journal of Business Research, 28(3), 191-210.

Mattoo, A., \& Wunsch, S. (2004, March). Pre-empting protectionism in services: The WTO and outsourcing (World Bank Policy Research Working Paper 3237, NY) Sourced from the web at 1813-9450-3237.pdf.

Morello, G. (1984). The 'made in' issue: A comparative research on the image of domestic and foreign products. European Journal, 12(1), 4-21.

Nebenzahl, I., Jaffe, E., \& Usunier, J. (2003). Personifying country of origin research. Management International Review, 43(4), 383-406.

Nunnally, J. (1978). Psychometric theory. New York: McGraw-Hill.

Okechuku, C., \& Onyemah, V. (1999). Nigerian consumer attitudes toward foreign and domestic products. Journal of International Business Studies, 30(3), 611-622.

Özsomer, A. (2012). The interplay between global and local brands: A closer look at perceived brand globalness and local iconness. Journal of International Marketing, 20(2), 72-95

Papadopoulos, N., \& Heslop, L. A. (Eds.). (1993). Product country images: Impact and role in international marketing. Binghamton, NY: Haworth Press.

Papadopoulos, N., \& Heslop, L. (2003). Country equity and product-country images: State-of-the-art in research and implications. In Handbook of research in international marketing. Northampton, MA: Edward Elgar.

Papadopoulos, N., Heslop, L. A., \& Bamossy, G. (1990). A comparative image analysis of domestic versus imported products. International Journal of Research in Marketing, 7(4), 283-294.

Pappu, R., Quester, P., \& Cooksey, R. (2007). Country image and consumer-based brand equity: Relationships and implications for international marketing. Journal of International Business Studies, 38(5), 726-745.

Pharr, J. M. (2005). Synthesizing country-of-origin research from the last decade: Is the concept still salient in the era of global brands? Journal of Marketing Theory and Practice, 13(4), 34-45.

Porter, M. E. (Ed.). (1986). Competition in global industries. Boston: Harvard Business School Press.

Reardon, J., Miller, C., Vida, I., \& Kim, I. (2005). The effects of ethnocentrism and economic development on the formation of brand and ad attitudes in transitional economies. European Journal of Marketing, 39(7/8), 737-754.

Reynolds, N., Simintiras, A., \& Diamantopoulos, A. (2003). A theoretical justification of sampling choices in international marketing research: Key issues and guidelines for researchers. Journal of International Business Studies, 34(1), 80-89.

Richardson, H., Simmering, M., \& Sturman, M. (2009). A tale of three perspectives. Organizational Research Methods, 12(4), 762-800.

Riefler, P., \& Diamantopoulos, A. (2009). Consumer cosmopolitanism: Review and replication of the CYMYC scale. Journal of Business Research, 62(4), 407-419.
Riefler, P., Diamantopoulos, A., \& Siguaw, J. (2012). Cosmopolitan consumers as a target group for segmentation. Journal of International Business Studies, 43, 285-305.

Roth, K., \& Diamantopoulos, A. (2009). Advancing the country image construct. Journal of Business Research, 62(7), 726-740.

Roth, M., \& Romeo, J. (1992). Matching product category and country-of-origin effects. Journal of International Business Studies, 23(3), 447-497.

Rugman, A., \& Oh, C. (2008). Friedman's follies: Insights on the globalization/regionalization debate. Business \& Politics, 10(2), 1-14.

Rugman, A., \& Verbeke, A. (2003). Extending the theory of the multinational enterprise: Internationalization and strategic management perspectives. Journal of International Business Studies, 34, 125-137.

Samiee, S. (1994). Customer evaluation of products in a global market. Journal of International Business Studies, 25(3), 579-604.

Samiee, S. (2010). Advancing the country image construct: A commentary essay. Journal of Business Research, 63(4), 442-445.

Samiee, S. (2011). Resolving the impasse regarding research on the origins of products and brands. International Marketing Review, 28(5), 473-485.

Schmitt, N., \& Kuljanin, G. (2008). Measurement invariance: Review of practice and implications. Human Resource Management Review, 18(4), 210-222.

Shankarmahesh, M. (2006). Consumer ethnocentrism: An integrative review of its antecedents and consequences. International Marketing Review, 23(2), 146-172.

Sharma, P. (2011). Country of origin effects in developed and emerging markets: Exploring the contrasting roles of materialism and value consciousness. Journal of International Business Studies, 42(2), 285-306.

Sharma, P., Mathur, R., \& Dhawan, A. (2008). Understanding consumer reactions to offshore outsourcing of customer services. In A. Becker (Ed.), Electronic commerce: Concepts, methodologies, tools and applications (pp. 92-104). Hershey, PA: Idea Group Inc.

Sharma, S., Shimp, T., \& Shin, J. (1995). Consumer ethnocentrism: A test of antecedents and moderators. Journal of the Academy of Marketing Science, 23(1), 26-37.

Shimp, T., \& Sharma, S. (1987). Consumer ethnocentrism: Construction and validation of the CETSCALE. Journal of Marketing Research, 24(3), 280-289.

Shukla, P. (2011). Impact of interpersonal influences, brand origin and brand image on luxury purchase intentions: Measuring inter functional interactions and a crossnational comparison. Journal of World Business, 46(2), 242-252.

Skrbis, Z., Kendall, G., \& Woodward, I. (2004). Locating cosmopolitanism: Between humanist ideal and grounded social category. Theory, Culture, and Society, 21(6), $115-136$.

Souiden, N., Pons, F., \& Kayrand, M. (2011). Marketing high-tech products in emerging markets: The differential impacts of country image and country-of-oringin's image. Journal of Product \& Brand Management, 20(5), 356-367.

Spillan, J., \& Harcar, T. (2012). Chilean consumers ethnocentrism factors and their perception regarding foreign countries products. Journal of Marketing Development \& Competitiveness, 6(1), 34-55.

Steenkamp, J., \& Baumgartner, H. (1998). Assessing measurement invariance in cross national consumer research. Journal of Consumer Research, 25(1), 78-90.

Steenkamp, J., \& de Jong, M. (2010). A Global investigation into the constellation of consumer attitudes toward global and local products. Journal of Marketing, 74, 1840.

Strizhakova, Y., Coulter, R. A., \& Price, L. (2008). Branded products as a passport to global citizenship: Perspectives from developed and developing countries. Journal of International Marketing, 16(4), 57-85.

Suh, T., \& Kwon, I. (2002). Globalization and reluctant buyers. International Marketing Review, 19(6), 663-680.

Ter Hofstede, F., Steenkamp, J., \& Wedel, M. (1999). International market segmentation based on consumer-product relations. Journal of Marketing Research, 36(1), 1-17.

Tse, D., Belk, R., \& Zhou, N. (1989). Becoming a consumer society: A longitudinal and cross-cultural content analysis of print ads from Hong Kong, the People's Republic of China, and Taiwan. Journal of Consumer Research, 15(4), 457-472.

Ueltschy, L. (1998). Brand perceptions as influenced by consumer ethnocentrism and country-of-origin effects. Journal of Marketing Management, 8(1), 12-23.

UNCTAD (2012). Sourced at: www.un.org/en/development/desa/policy/. . ./2012country_class.pdf..

Usunier, J. (2011). The shift from manufacturing to brand origin: Suggestions for improving COO relevance. International Marketing Review, 28(5), 486-496.

Usunier, J., \& Cestre, G. (2008). Further considerations on the relevance of country-oforigin research. European Management Review, 5(4), 271-274.

Vandenberg, R., \& Lance, C. (2000). A review and synthesis of the measurement invariance literature: Suggestions, practices, and recommendations for organizational research. Organizational Research Methods, 3(1), 4-69.

Verlegh, P., \& Steenkamp, J. (1999). A review and meta-analysis of country-of-origin research. Journal of Economic Psychology, 20(5), 521-546.

Vida, I., \& Reardon, J. (2008). Domestic consumption: Rational, affective or normative choice? Journal of Consumer Marketing, 25(1), 34-44

Vida, I., Dmitrovic, T., \& Obadia, C. (2008). The role of ethnic affiliation in consumer ethnocentrism. European Journal of Marketing, 42(3/4), 327-343.

Wang, C., \& Chen, Z. (2004). Consumer ethnocentrism and willingness to buy domestic products in a developing country setting: Testing moderating effect. Journal of Consumer Marketing, 21(6), 391-400.

Wang, L., Li, D., Barnes, B., \& Ahn, J. (2012). Country image, product image and consumer purchase intention: Evidence from an emerging economy. International Business Review, 21, 1041-1051.

Wang, X., \& Yang, Z. (2008). Does country-of-origin matter in the relationship between brand personality and purchase intention in emerging economies? Evidence from China's auto industry. International Marketing Review, 25(4), 458-474. 
Watson, J., \& Wright, K. (2000). Consumer ethnocentrism and attitude toward domestic and foreign product. European Journal of Marketing, 34(9/10), 11491166.

World Bank (2010). The World Bank Annual Report 2010. http://siteresources.worldbank.org/EXTANNREP2010/Resources/WorldBank-AnnualReport2010.pdf
Yip, G. S. (2000). Global strategy in the Internet era. Business Strategy Review, 11(1), 1 -

Zeugner-Roth, K., Diamantopoulos, A., \& Montesinos, M. (2008). Home country image, home country brand equity and consumers' product preferences: An empirical study. Management International Review, 48(5), 577-602.

Please cite this article in press as: Jin, Z., et al. The relationship between consumer ethnocentrism, cosmopolitanism and product country image among younger generation consumers: The moderating role of country development status. International Business Review (2014), http://dx.doi.org/10.1016/j.ibusrev.2014.08.010 